From Spiritual Houses to National Shrines:

Religious Traditions and Nation-Building in Vietnam

Roszko, Edyta

Published in:

East Asia

DOI:

DOI. $10.1007 / \mathrm{s} 12140-011-9156-x$

Publication date:

2012

Document version

Publisher's PDF, also known as Version of record

Citation for published version (APA):

Roszko, E. (2012). From Spiritual Houses to National Shrines: Religious Traditions and Nation-Building in Vietnam. East Asia, 29, 25-41. [4]. https://doi.org/DOI. 10.1007/s12140-011-9156-x 


\title{
From Spiritual Homes to National Shrines: Religious Traditions and Nation-Building in Vietnam
}

\author{
Edyta Roszko
}

Received: 6 March 2011 / Accepted: 18 July 2011 / Published online: 3 September 2011

(C) Springer Science+Business Media B.V. 2011

\begin{abstract}
As in China and Soviet Russia, religion in Vietnam was considered to be harmful superstition. However, a glimpse into the Governmental Gazette - Công Báo - displays the important transformation of the state's policy toward religion that became translated into national representation. While this article focuses on nationbuilding as a dynamic cultural process that leads to the promotion of selected religious practices as 'national heritage,' it also explores the state-society relationship beyond binaries. By looking at religious spaces and local communities I argue that in Vietnam religion is a powerful form of nation-building process and constitutes a creative space in which different actors exercise their agency beyond resistance and accommodation.
\end{abstract}

Keywords Cultural heritage $\cdot$ Nation-building $\cdot$ National heritage $\cdot$

Religious traditions $\cdot$ Vietnamese modernity

Visitors to Vietnam might find themselves confused by the diversity of venerated spirits and gods who exist in multiple variations in many localities, dwelling in mountains, forests, rivers and the sea. Like saints worshipped by Catholic believers, many of those spirits were born as humans and their biographies were marked by unusual events. However, in contrast to Christian saints, in their earthly existence Vietnamese spirits were neither ascetic nor austere. Therefore, the visitors would be astonished to find that violent and enigmatic death that breaks the natural order, such

E. Roszko $(\square)$

Max Planck Institute for Social Anthropology, Halle, Germany

e-mail: edytaroszko@googlemail.com 
as suicide and capital punishment, or crime and sin have turned common people and even criminals into powerful spirits worshipped as guardians in village temples.

Yet, religion in Vietnam could be defined neither in terms of blending indigenous beliefs with those belonging to the so called 'great traditions' (Buddhism, Confucianism and Daoism) nor as a Vietnamese syncretic religion, as suggested by some scholars in Vietnam (see [51]) for the simple reason that no Vietnamese people would define their religion in such terms. Oscar Salemink [45] pointed out that we should deal, rather, with the "interconnection and mutual influence between major religious traditions in Vietnam, through a wide variety of rituals and in overlapping cosmologies and pantheons associated with Buddhism, Daoism, and Confucianism (...), built on a substratum of ancestor worship." Thus, we could say that ancestor worship is a long-standing religious tradition deeply rooted in the consciousness of the Vietnamese people. It is the custom of venerating those who simply passed away, who collected merit through good acts for their family, village or country or, on the contrary, broke moral rules and a village's social order and for that reason are worth worshipping by individuals and local communities.

Since the Đổi Mới [Renovation] reforms, the historical and mythological spirits enshrined in the freshly restored buildings and sustained by diverse revitalized religious practices, blend with the commercialization of everyday life and the global capitalist version of 'modernity' that Vietnam has adopted just recently [49]. Along with these acute social changes, the socialist state nervously tightens its grip on Vietnamese society by strengthening cultural campaigns to preserve 'authentic' Vietnamese traditions and promotes its own version of modernity after its withdrawal from a socialist modernity. Perhaps the most telling example is "Resolution No. 5 on Building a Progressive Culture, Imbued with National Identity," adopted in 1998 by the Central Committee of the Communist Party. ${ }^{1}$ This Resolution created the basis for the Party-State to identify selected religious beliefs, customs and rituals as part of 'national culture' and, thus, opened a space for "alternative historical and cultural narratives of the Vietnamese nation" [46]. I return to this important document later in this article.

As Keyes et al. [30] demonstrate in their seminal volume Asian Visions of Authority, the thesis that modernization and re-structuring of Asian societies in the name of 'progress' would lead to their secularization, as predicted by Marx, Durkheim and Weber and their followers, failed to materialize. The marginalization of the religious sphere did not lead to a break with religious traditions but quite the opposite; along with modernization they became even more significant ([30], p.3). The authors aptly point out that state agendas to control and standardize religion have been formed not only by theories of modernization which sought to free people from superstitious and time-consuming practices, but also by the need of Asian modern states to legitimize their rule and consolidate the 'masses.' This necessity expressed in the nation-building process entailed a different attitude to the past and to religion from that of socialist modernizing agendas.

\footnotetext{
${ }^{1}$ See Nghi quyết hội nghị làn thư năm Ban chấp hành Trung uơng Đảng (khóa VIII) về xây dựng và phát triển nền văn hóa Việt Nam tiên tiến, đậm dà bản sắc dân tộc [Resolution No.5 of the Central Committee of the Communist Party on building progressive culture, imbued with national identity], số 03/NQ-T ngày 16/17/1998, retrieved on 2 December 2010 from http://www.na.gov.vn/sach_qh/chinhsachp1/phan1/ p1_iv_16.html
} 
Most generally, this article is intended as a contribution from an anthropological perspective to the wider literature theorizing and comparing the contemporary nation-building process. By nation-building I understand a dynamic cultural process that leads to the promotion of selected practices and the constant invention of new rites (cf. [27, 30, 47]). Claire Sutherland [47] draws our attention to the fact that contemporary nationalism as propagated by parties, movements and states mobilizes people in a drastically different milieu to the nineteenth century variants discussed, for example, by Gellner [26]). She emphasizes that theoretical debates referring to contemporary nationalism must consider "its strategic flexibility in the face of changing state, sub-state and supra-state relationships" ([48], p. 69).

Along these lines, I attempt in this article to tackle the question of how religion and nation-building ideology in Vietnam co-exist and how the state seeks to mobilize the 'masses' to shape its powerful project of national representation. In modern Vietnam a vast repertoire of religious traditions competes with the official ideology, since the Party-State has attempted to control and appropriate religion as a representation of culture and nation. Such institutionalization of religion serves the state's purpose to legitimize its power and engage people in institutional and emotional actions and foster a sense of national unity. In order to better understand this process, I open my discussion with a brief analysis of the Governmental Gazette Công Báo, which reveals how the State-Party appropriates and internalizes religious spaces as forms of nation-building in an attempt to pursue its nationalist project. In the subsequent part of this article I shall argue that the recent resurgence of religion in Vietnam shows that the state does not have the last word in the symbolic sphere and that people are active actors shaping a national drama in which religion plays its part. Therefore, the last section aims to illustrate some of the tensions between people's religious ideas and practices and the official co-option of religion as an element of nationhood.

\section{Religious Buildings as a Form of Nation-Building}

Like in China, in Vietnam the ongoing process of the state taking control over religious affairs in local communities was an attempt to "disenchant" [56] and simplify the local landscape in order to make it predictable and manageable. The first task of the state was to divest religious places of their sacred aura and show that local gods were nothing more than powerless effigies. This was done by removing sacred objects from temples, shrines, and pagodas and turning structures that were not destroyed into functional buildings.

Paradoxically, at the same time, in the Vietnamese official discourse there was a tradition of preservation of communal houses, temples, and shrines going back to 1945 when Hồ Chí Minh issued a decree in the context of land reform on protecting cultural heritage [di sản văn hóa] [21]. Historian Patricia Pelley [41] demonstrates clearly that the Vietnamese postcolonial socialist state, ceaseless in the defense of the country against foreign aggressors, was extremely concerned about national history and its interpretation. As early as 1943, the Vietnamese Communist Party, in its "Theses on Vietnamese Culture" introduced three principles: nationalization, popularization, and scientism [dân tộc hóa, đại chúng hóa, and khoa học hóa] as 
the "guiding concepts for the project of building a "new culture' and a 'new life" ([23], p. 2; see also [38], p. 26-46). 'Nationalization' especially was understood as a defense against hostile forces - France and Japan - in terms of a "long-standing tradition of resistance to foreign aggression" and, therefore, occupied a particular place in the ideological and academic discourse ([23], p. 2). In the 1950s, 1960s, and 1970s scholars debated extensively about turning points in Vietnam's history as well as about the historical figures concerned, which were often 'repacked' and represented as national heroes [41]. Such repackaging did not only refer to historic figures, but also included religious structures which in the official view stood for a "national tradition." Close reading of the Official Gazette Công Báo, from 1953 onwards reveals three phases in the official policy toward the local religious domain, namely transformation of religious buildings into (1) 'secular spaces'; (2) 'cultural heritage'; and (3) 'national heritage.' At the same time, however, it reveals that Hồ Chí Minh's directives were largely ignored.

In the North, during the land reform (1953-1955) and the time of collectivization and dependence on the state's handouts (1975-1986), religious buildings suffered extensive destruction and neglect as their facilities and properties were claimed by village agricultural co-operatives or simply cleared of clergy and left empty. The monks and nuns who depended largely on these properties were dissociated from the basis of their livelihoods. During the land reform, those pagodas that temporarily maintained their plot of land were taxed and their clergy was expected to work in its rice fields shoulder to shoulder with villagers, instead of relying exclusively on the labor of religious followers $[5,6]$.

Comparing individual issues of Công Báo, it becomes apparent that the state had its own vision of how to make use of temples, although it was not always clear and consistent in its policies toward religious spaces. As a result, the state's inconsistency widened a gap between the official goals of a new usage of sacred spaces and their implementation. Moreover, the implementation of the new ideological agenda was not always as peaceful a process as the state intended. Ten years after Hồ Chí Minh issued his directives on protecting cultural heritage, Prime Minister Phan Mỹ in the Công Báo of 1956 lamented the pitiful situation of destroyed sites of local cults, which in the official discourse underwent a metamorphosis into "historical monuments" $[d i$ tích lịch sü], "heritage of feudalism" [di sản của phong kiến] or "monuments of resistance to foreign aggression" [di tích kháng chiến] ([7], p.189). Thus his lament referred to the dilapidation of these buildings because they were officially of national, not religious significance. However, as the next issues of Công Báo show, in the process of appropriation of religious buildings for secular purposes, national aspects were often ignored by local cadres as well as villagers.

Specifically, religious structures were demolished not only by the communist guerillas, who had used well-tried scorched earth tactics in order to deny the enemy any space to quarter their troops, but also by villagers who tore down the buildings or simply used their material for constructing their own houses. Consequently, in Công Báo's later issue of 1960, the state showed its disquiet over popular reactions and feelings about the "dilapidated situation of temples falling into ruins [đỏ nát] and with pieces lying scattered around [hốn độn]," which might have resulted in a "negative political impression among local visitors and foreign guests," and recommended to provincial offices of culture and the People's Committees to 
remove all defacements from monuments and to beautify the local landscape by planting trees ([8], p. 338).

In its rhetoric, the government proclaimed that although the "communal houses, Buddhists pagodas, shrines, temples, and imperial tombs have for centuries been exploited by feudal tyrants, who turned them into places giving them prestige in order to be close to all classes of people and to sow superstitions to captivate people," they should be utilized in accordance with a new cultural project of building a modern nation ([8], p. 338). As I have already noted, the state's concern was dictated by practical considerations to develop them as places of historical interest, cultural value, or scenic beauty that the masses could visit as tourists, rather than as places of religious activity. More importantly, this development aimed to replace superstitious beliefs with a new socialist creed. Thus, the fate of these places was not a trivial and unimportant matter since their new role was supposed to substitute for their religious function and to serve the state machinery in building a new society. The Ministry of Culture, conscious of losing control over the management of temples and of the fatal consequences of anti-religious zeal, blamed its own followers for "lack of proper view" (ibid.). In a self-critical mood, the Công Báo ([8], p. 338) describes the temples' destruction:

....as a result of the need for material for building new projects, a number of the objects of our age-old architectural legacy [heritage - di sản kiến trúc cổ truyền] have been demolished; some of them have been used to support the art of cooperatives [văn nghệ hơp tác xã] or the production of oil lamps for meetings, others have been turned into retail outlets, storehouses and markets; while some of them remain in the hands of superstitious old ritual masters, the majority has no one looking after them; some people with little consciousness destroyed these places or used them as private houses.

Then, it continues:

It is prohibited to defile architectural monuments [công trình kiến trúc] or to use them in illegitimate ways such as: making improper drawings on the walls, pillars, and statues, or on the objects of worship; raising chickens and ducks; piling straw; storing excrement in communal houses, pagodas, shrines, and temples, or imperial tombs [lăng tẩm]; taking memorial plaques, tiles, wood, wooden panels with Chinese characters, or lacquered boards belonging to communal houses in order to demolish them or to make piers, plank-beds, or chairs or to bake lime ([8], p. 338).

To rectify all "committed mistakes and shortcomings," local authorities were strongly encouraged to protect and preserve "all old architectural and other locales of scenic beauty and to use them in an appropriate way without wastage" (ibid.). The 'appropriate way' was understood as "turning all places of worship into schools, exhibition halls, gathering places, and cultural houses," which in the official discourse, were presented as places of education and thus better alternatives for once sacred locations (ibid.). However, before implementing state policy the same issue advised local government to consult with villagers, owners of religious buildings and provincial cultural offices about the most suitable form, in their view, of use for religious structures. According to the government order, all sites of historical interest 
including sites of scenic beauty that could be Buddhist pagodas and temples were managed by local People's Committees [uỷ ban nhân dân] and cultural offices [sở văn hoá] [9]. In practice it meant that any renovation and construction work in places of worship and of historical and cultural value had to be officially approved by these bureaus. This rule is still obeyed in Vietnam.

After the public admission in the Công Báo of 1960 of shortcomings in the management of religious structures, the next six years did not bring a significant improvement in the situation and the Party had to sharpen its tone. Still in a selfcritical mood, Prime Minister Phạm Văn Đồng reacted to the destruction of pagodas and temples by pointing out the poor record of administrative committees [uy ban hành chính] to "preserve all places of historical interest, to teach people about their value and to transform them into museums" ([10], p. 270). He stressed that these places have been lost and destroyed due to the lack of interest or even awareness of the official duty of preserving the historical monuments [di tich lich sü], and, hence, to the low level of training of local cadres (ibid.).

In 1973, two years before the end of the Vietnam War, the state, specifying its policy toward Buddhist pagodas and the clergy, had to again remind local authorities of the policy of protecting all places of historical and cultural interest. The government directive ([11], p. 253) called for "preserving thoughtfulness [chu đáo] and cleanliness [sach sê]" vis-à-vis Buddhist pagodas and forbade "hurting the feelings and beliefs [tín nguõng] of the people" by destroying Buddhist sculptures and instruments or using them in an inappropriate way. Vice-Prime Minister Lê Thanh Nghị reminded authorities in all communes $[x \tilde{a}]$ and cities $[k h u$ phố] that they have a duty to coordinate mass organizations [tố chức nhân dân] responsible for protecting and "bringing into play the notion of historical monuments" (ibid.). He pointed out that these committees must invite and help monks and nuns to take direct responsibility for the protection and preservation of 'historical spaces' but, at the same time, they should not interfere with religious activities. Therefore, the state was concerned not about religious but, above all, national spaces.

Theoretically, the Buddhist clergy could count on official guarantees to continue their religious activities if they voluntarily handed their land to the village cooperatives and joined common production. The co-operatives were expected to assign the monks and nuns to brigades based on practical abilities and their religious tasks in order to ensure their livelihoods [11]. In reality, however, the clergy had little choice: the state recommended training the most suitable local clergy as tour guides. It was supposed that monks and nuns could help local cadres with instructing visitors on the history of pagodas and scenic sites ([11], p. 253).

One year later, in attempts to complement the policy of "preservation" and "protection" the state introduced a procedure of "classification" [xếp hang] of pagodas and temples as "historical and cultural monuments" [di tích lịch sù và văn hóa] ([12], p. 51). Note that the Ministry of Culture for the first time added the adjective "cultural" [văn hóa] to the term "historical monument" (ibid.) and, consequently, broadened the definition of 'heritage'. The subsequent issue of 1975 continued to list 12 pagodas and temples that qualified according to this new criterion [13]. However, between 1975 and 1979 - the time of the most zealous antisuperstition campaigns and destruction of many religious buildings in the South the Công Báo kept notable silence over the protection and preservation of temples. 
At the beginning of the 1980 s the state returned to its policies of preserving historical sites. In consequence, the next issues of the Công Báo continued classifying temples according to their historic, cultural and artistic importance [14, 15]. In 1984, when the instructions concerning cultural preservation received a higher legal status of 'state law' [pháp lệnh] the provincial authorities were encouraged to apply for official recognition of all cultural and historical sites ([16]; see also [23], p.5). Judging from the growing number of official recognitions published in the Công Báo after 1984, the state's initiative met with an enthusiastic response from local officials and villagers. ${ }^{2}$ All these events took place on the eve of the Đổi Mói $i$ reforms.

For a further analysis of the Công Báo and the Party-State discourse on culture it is necessary to take into account this significant turnaround in Vietnamese politics. Since the introduction of the Đổi Móri Reforms in 1986, Vietnam gradually withdrew from a socialist modernity and opened its borders to the international community. As a consequence of the much more liberalized environment, traditional religious practice experienced a phenomenal revival. At the same time, integration with global capitalism posed an enormous threat of an inundation of foreign culture, prompting the state to attempt to devise an alternative Vietnamese vision of modernity in which national identification was the main indicator [45]. As already mentioned at the beginning of this article, a milestone in the state's policy on preservation of those local cultural practices that would simultaneously symbolize 'traditional' and 'modern' was "Resolution No. 5 of the Central Committee of the Communist Party on Building a Progressive Culture, Imbued with National Identity," which was adopted in 1998. Although this Resolution does not refer explicitly to religion, it nevertheless allowed for the interpretation of religious revival in terms of 'culture' and, above all, 'national heritage.' Oscar Salemink [46] interprets Resolution No. 5 as, on the one hand, an "umbrella for all sorts of local, bottom-up efforts to reinvent traditions and invest these with new forms and meanings," and on the other hand, a useful tool for the state to "claim a greater role in the organizations of rituals and festivals (...) in an attempt to channel the discourse over Vietnam's identity in new directions after the withdrawal from Socialist modernity."

Due to its particular emphasis on the national aspect of Vietnamese modernity, it seems that the Party Resolution No. 5 is much more binding for official authorities and even academics than the 2001 State Law on Cultural Heritage published in the Công Báo ([17], p. 2232). While the 2001 law describes in general terms "cultural heritage" as a "spiritual product which has historical, cultural, and scientific values preserved in memory, writings and handed down orally, through art and craft, science, oral philology, folk performances, a way of life, a traditional lifestyle, festivals, handicraft techniques, knowledge of traditional medicine, food culture, traditional national costumes, and different terms of folk knowledge," the Resolution No. 5 offers reconciliation between divergent tensions such as "socialism" and "market" or "cultural chauvinism" and "cosmopolitanism" [46].

In 2002, specifying the 2001 Law on Cultural Heritage, the government pointed out that historical and cultural sites had to meet at least one of the three criteria of (1)

\footnotetext{
${ }^{2}$ Based on her survey in archives of the Ministry of Culture, Endres [23] points out that until 1996, altogether 1860 historic sites and monuments were officially recognized as historical and cultural sites.
} 
"provincial" [tỉnh], (2) "national" [quốc gia], and (3) "special national" [guốc gia đặc biệt] significance. While the first criterion referred mainly to archeological, historical and cultural sites important for local regions, the two latter criteria stressed explicitly national aspects of such places. More precisely, the Law of 2001 indicates that all places designated as "national" [ di tích quốc gia] and "special national monuments" [di tích quốc gia đặc biệt] must refer to important events in national history or to "national heroes" [anh hung dân tộc] or "famous symbolic persons having influence on the course of national history" ([18], p. 4051). In the further part of the Công Báo of 2002, Prime Minister Phan Văn Khải gave a detailed list of all documents necessary to apply for the official recognition usually known as "Certificate of Designation of a Historical and a Cultural Relic" [công nhận di tích lịch sư văn hóa]. In most cases, it was required that the file for application, certified by local authorities, must include a "life story," a written statement by applicants, and a map with the exact location of the site (ibid.).

Paradoxically, the modern practice of the socialist state to grant certificates to heroes, divinities, and temples with historical and national importance has a long tradition in Vietnam, dating back to imperial times (see [3, 19, 20, 57, 59]). By the sixteenth century the Lê dynasty attempted to gain control of the spirit cults in the villages through the establishment of a spiritual hierarchy for the spirit world that fitted the Confucian model. ${ }^{3}$ Spirits were certified with a royal charter [sắc phong] and, at the same time, their 'spirit record' [thần tích] was standardized and cleansed of elements that were not congruent with dominant and official ideology. The central authorities required that the new spirits had to be those of deceased individuals who had been moral exemplars or good officials. The central state acted as patron of these spirits and through their standardization tried to integrate the country and enforce a sort of unity on regional and local levels. A closer reading of the Công Báo shows a continuity of the postcolonial socialist Vietnamese state with this pre-colonial practice. Like the imperial court, the modern state seeks to increase its legitimacy through the careful selection and canonization of those historic figures who demonstrated moral and patriotic values and heroic resistance against foreign invaders (see [33], p. 529; [41], p. 177-189; [42, 44]).

In line with the slogan of Resolution No. 5 of "building a progressive culture, imbued with national identity", local state agents are encouraged to apply for official recognition of commemorative sites of an artistic and historic value or the historical or cultural character of the residing deity, which they can prove have the potential to be included in the category of "cultural heritage" ([22, 23], p. 6). At the same time, villagers who want to re-claim their sacred spaces and to reaffirm their institutional significance try to obtain such a certificate which not only provides state recognition for the temple but also, like in the imperial past, enables people to worship their divinities in any way they wish; and it is also a source of personal consolation and communal pride.

\footnotetext{
${ }_{3}^{3}$ Already in the thirteenth century the Trần court - fervent Buddhists - honored the villagers' tutelary spirits, however such practices were not the same as imperial control over spirits initiated in sixteenth century by the Lê dynasty. By the fifteenth century Đại Việt shared many patterns with its Southeast Asian neighbours; Mahayana Buddhism and the spirit cult were the main forms of popular beliefs. Chinese NeoConfucianism with its rigid moralistic ideology only began to have a more significant impact in the Lê period ([58], p. 298; see also [59], p.11-12; [52]).
} 
However, as Salemink [46] points out, the state recognition goes beyond the cultural and historical assessment of the site as heritage since the state "authenticates, reifies and instrumentalizes local process under the umbrella of the nation." By giving local practices and the spaces the label of 'cultural' and 'national heritage' the state appropriates them for its own purposes. This involves not only selection, appropriation, and changing meanings but also controlling and disciplining the people who are emotionally engaged in rescuing their sacred sites (ibid.). Anagnost [2] defines this process as the "politics of ritual displacement," a sort of "uneasy accommodation" that engages both the local community and the state in a struggle over the symbolic meanings of temples.

To sum up, in this section I have aimed to underline that the public admission of shortcomings in the Công Báo was not tantamount to a lessening of the tension between religion and official ideology. At the same time, I sought to demonstrate that the state itself is an arena of diverging interests and changes over time; thus the official policy toward sacred buildings continues to be redefined and adapted to the 'spirit' of the times. As we have seen, the communist procedures of converting temples into secular places were replaced with the new guidelines on how to transform them first into 'cultural' and, then, into 'national heritage' sites as better substitutions for sacred locations. Keeping in mind all these changes in the official policy, in the next section I will demonstrate more explicitly through ethnographic description how local communities link their endeavours to promote particular spirits with nation-building processes, in order to gain state support for the recognition of their sacred spaces.

\section{The Quest for 'National Heritage'}

In August 2007 I finished my ethnographic field research on popular religion and the various intersections between religion and politics in the coastal province of Quảng Ngãi, Central Vietnam, and returned to Germany to begin writing my dissertation. The villagers from Lý Sơn Island phoned me several times. I was astonished to hear their thanks for my help in elevating Âm Linh Tự Temple [Temple of the Dead] to the rank of 'national heritage'. Although I protested and tried to explain that I had not played a part in this process, they have their own understanding of the matter. They came to the conclusion that the presence of a foreign researcher on the island added legitimacy to the provincial authorities' endeavors to obtain a 'National Certificate of Designation of Historical and Cultural Relic' issued by the Ministry of Culture, Sport and Tourism.

In the early 1990s the Vietnamese State turned its attention toward Lý Sơn as a valuable source of information about the soldiers of the nineteenth century Hoàng Sa (Paracel) and Trường Sa (Spratly) navy (see Lê Qúy Đôn, [32]; Nguyễn Nhã [37]). ${ }^{4}$ In 2001 it issued a directive establishing a commemorative site for the two flotillas. Facing competition from China for control over the Paracel and Spratly

\footnotetext{
${ }^{4}$ The Hoàng $\mathrm{Sa}$ and Trường $\mathrm{Sa}$ flotillas were established by the Nguyễn lords around the turn of the sixteenth and seventeenth centuries. Throughout the eighteenth and nineteenth centuries the Nguyễn dynasty continued to carry out naval activities in the vicinity of the Paracel and Spratly archipelagos.
} 
archipelagos, the Vietnamese Party-State chose to frame its claims of sovereignty over the archipelagos not in economic terms but with reference to historical, emotive stories of Vietnamese sailors who shed their blood on the islands. As I described elsewhere, many of the Hoàng Sa soldiers died at sea and their bodies were never returned to their relatives, giving rise to special ritual and memorial practices in Lý Sơn [43].

At the time of my fieldwork in 2007, the commemorative endeavors of the Vietnamese State devoted to glorifying Hoàng $\mathrm{Sa}$ and Trường $\mathrm{Sa}$ navy and to the preservation of all temples and records related to Hoàng Sa and Trường Sa sailors' activities on Lý Sơn Island still had a low profile. Moreover, Lý Sơn Island did not appear on most official maps, which did include the Paracels and Spratlys, in spite of the efforts by Quảng Ngãi provincial authorities to present the island not only as a historical treasure trove but also as a potential tourist destination. Although local commemorative traditions attracted the attention of regional media, including Đà Nẵng television which produced several documentary films about the individual lineages' religious observances, I could hardly find any information about Lý Sơn on the internet. However, in 2009 the situation changed dramatically as the island became the topic of many internet debates due to an unexpected 're-discovery' of a cultural and historical legacy 'preserved for centuries' by islanders. Lý Sơn, widely publicized in the context of the Paracels and Spratlys dispute, became a symbol of a putative long-standing consciousness of protecting the 'ancestral lands' in the South China Sea, provoking mediated sentiments of a new-found patriotism among Vietnamese nationalists and especially students, who staged several peace rallies to demonstrate their national devotion, perhaps tinged with some sort of anti-Chinese sentiment.

From 1974 onward, when Chinese forces overran a South-Vietnamese military station on the Paracels, China and Vietnam began to confront each other over control of the Paracels and Spratlys, resulting in the downing of three Vietnamese naval ships by Chinese forces in 1988 [1]. In spite of competing claims to (parts of) the Paracel and Spratly archipelagos, up until the 1990s the South China Sea was considered open sea and the fishing grounds were considered common property. With the discovery of submarine deposits of natural oil and gas, both states do not just claim sovereignty over the islands but also seek to extend their sovereignty over the entire continental shelf, incorporating the South China Sea and its mineral and marine resources under their respective control.

Paradoxically, the commemorative project of the central State as well as the national and international attention in the mass media to the Paracels and Spratlys dispute opened up a new space of possibilities for the marginalized community of Lý Sơn fishermen, who began to manifest themselves through the 'Hoàng Sa-Trường Sa project.' The Vietnamese state not only faced international but also local contestations, since islanders offer their own accounts of this emotionally charged issue. Within the scope of scientific and official interest in the historical past of the South China Sea region, they were encouraged by provincial authorities to reveal all existing written documents that might have historical value and contribute to the reconstruction of 'patriotic traditions' on the islands. In spite of the official attempt to keep the campaign of 'protecting ancestral lands' in the South China Sea manageable, the project inscribed itself into a wider context of international affairs. 
Confronted with a large-scale mobilization campaign, many lineages actively participated in the official initiatives, hiring even historians, journalists and TV reporters to publicize their case; however, the outpouring of genealogies and documents referring to the Paracel and Spratly archipelagos was not always congruent with official expectations (see [43]).

Parallel to the competition between various lineages, provincial authorities saw a chance to promote their own province and elevate themselves to higher state positions by catering to Hanoi's 'official interest' in patriotic traditions on the island. Since 2007, Quảng Ngãi authorities have invested over $\$ 700,000$ to build the Hoàng $\mathrm{Sa}$ /Trường Sa memorial on Lý Sơn Island, a project that includes a museum, a restored communal house and a monument dedicated to the Hoàng Sa flotilla. ${ }^{5}$ Furthermore, the Provincial Cultural Office decided to 'recover' local traditions connected with the Hoàng Sa soldiers and even turned to the Ministry of Culture with the request to give the commemoration ceremonies the status of national festival. Additionally, they became directly engaged in helping selected lineages restore their temples and provide funds for organizing traditional ceremonies related to Hoàng Sa sailors. In the spring of 2009 the Quảng Ngãi Provincial Authorities took over all responsibility for preparing the Hoàng Sa Soldiers' Tribute Ritual from the Lý Sơn villagers, who complained that they were not allowed to conduct the ceremony according to their local views.

\section{Strategies of the Vietnamese People to Cope with the State's Nation-Building Project}

The short ethnographic vignette introduced above suggests that the process of restoring religious practices in Vietnam is taking place on two overlapping levels. In the public discourse, there is approbation and encouragement for obtaining official recognition of historic figures who have demonstrated moral and patriotic behaviour by heroically resisting foreign invaders, and of gods and spirits with a long-standing presence in popular religion. As Taylor [50] points out, the state is "quite accommodating" toward the religious domain provided that it is compatible with its own interests. Privately, however, local officials and local communities often have their own ideas and motivations regarding the recovery of local memories and sacred spaces, as the Lý Sơn example shows. Villagers might promote particular spirits, which they pursue independently of state directives. Therefore, I argue that Vietnamese people neither resist nor submit to the state's nation-building project. Rather they engage with the state's nation-building, showing their agency exercised in the articulation of their locality in a way that fits into national discourses. The relationship between the state and the local community is much more flexible and dialogical than can be assumed in a country where the Party-State outlines the legal, social, and political constraints on religious space. Such a perspective goes beyond a simplistic view of the role of religion in Vietnam as the renewal of traditions, the

\footnotetext{
${ }_{5}^{5}$ See VietNamNet 1 May 2010, http://english.vietnamnet.vn/politics/201001/Paracel-and-Spratly-flotillapreservation-underway-887929/, accessed on 7 September 2010.
} 
people's resistance or state co-option, and suggests that both the state and society are "mutual protagonist[s]" in the recent revival of religion ([50], p. 13).

As we have seen, a confrontation happens not just between the two sides - state's nation-building project and society - because neither of them constitutes a "monolithic entity with a singular agency," but rather between multilevel "arena[s] of contestation in which conflicting interests are played out and resolved" ([46]; see also Migdal [36]). To summarize my argument, there is no clash of views between 'the state' and 'the people,' because there is not one state view and not one people's view. In other words, the state consists not only of institutions and policies but also of norms and values which are articulated by its various cultural initiatives, projects, and tasks as acted out by diverse producers [53, 54]. Their interpretations vary depending on region, interest, and position. In consequence, people are not just confronted with the state per se but with its multiple identities taking the shape of local agents and intellectuals including anthropologists, folklorists, historians and archeologists, just to name a few, who have diverse visions and are never outside of a web of social relations. In turn, 'the people' are neither a uniform category nor a harmonious group as they are divided not only by age, gender and class, but also by different aims and aspirations. All these groups and individuals have different memories and interpretations of history, and they often adopt conflicting strategies to achieve their goals. As I showed, Lý Sơn islanders attempted to turn their kin into heroic and meritorious members not only to back the state-fostered nation-building narratives surrounding Hoàng $\mathrm{Sa}$ and Trường $\mathrm{Sa}$ commemorations, respectively Paracels and Spratlys territorial disputes, but also to determine who belongs to the community and shares the same 'national heritage.'

The relationships are never equal: there are always those who are more powerful due to their position, knowledge, connections and so forth. However, even the 'subordinates' are not entirely deprived of 'agency' and also have powers and projects of their own [40]. Ortner [39], drawing on Comarroff's [4] study of the ways in which the Tswana consciousness has been transformed during their encounter with missionaries, argues that in the relationship between the dominant and the subordinate the latter group does not just simply produce a mechanical reaction, but has its own strategy which is the outcome of frictions and tensions between various local categories within the group itself. Hence, agency is always part of a process, is culturally and historically constituted and never free, but always interactively negotiated. Ortner [40] distinguishes between "agency of power" which is organized around domination and resistance of one person/group over other(s), and "agency of projects" that is defined by a culturally constituted logic of the good and the desirable. The two types of agency are in practice inseparable because both domination and resistance are always defined by prospective goals, as people seek to achieve them in their own culturally and historically established terms (ibid.).

Achille Mbembe [35] also pays attention to the "agency" of the "subject" and her/ his confidence in his- or herself, although he does not use such a term to describe relationships of power in the African 'postcolony'. However, I have found his insights useful when thinking about the strategies that Vietnamese people undertake to accomplish their aims in situations when the state attempts to control and standardize public and social life to define collective goals and to proclaim the unity of the society. Similar to Ortner, Mbembe [35] advocates going beyond binary 
categories in the interpretations of domination and resistance. He argues that the relationship between state and people is not in a dialectic of 'either' resistance 'or' collaboration, but that it could rather be characterized as a "promiscuous relationship," a "convivial tension between the commandment and its "target"" (ibid, p.5). In this relationship, which he calls "indiscipline" and "insubordination", people have to learn how to manipulate the "representation that state power projects of itself and society" and how to bargain and improvise in order to pursue their goals (ibid, p.7). Therefore, I argue that Vietnamese people do not just adapt to the state nationbuilding project. On the contrary, their most commonly deployed strategy is the integration and adjusting of personal narratives to official histories, with a view to gaining the government's recognition of ancestors, divinities and heroes.

\section{Conclusion}

In this article, I have highlighted that in the Đổi Mói period the Vietnamese state relaxed its anti-superstition campaigns and allowed for a certain degree of religious freedom, albeit in the framework of detailed prescriptions, proscriptions and guidance. Sketching a detailed analysis of the state's strategies to standardize, normalize, control and appropriate religious traditions, I drew attention to the reverse process, namely how Vietnamese people deal with the state. I introduced people's strategies to respond to the official cultural policy and argued that the relationship between state and local community transcends the standard dichotomy of resistance and domination and is more complex than such dualistic visions predict. Such a conceptualization of relations between 'dominant' and 'dominated' enabled me to grant more agency to the latter and opened up new space for rethinking what their position is vis-à-vis the state.

At this point it is worth emphasizing the impact of the state cultural policy on religious traditions in Vietnam. When globalization and 'foreign' culture became a real threat, the state spared no efforts in connecting religious revival with nationalism. When the Party Central Committee adopted Resolution No. 5 in 1998, the religious revival "began to be translated into the official imaginary of the nation" ([45], p. 276). In light of this document, ancestor worship, communal houses and rituals associated with them appeared to be legible to the state in the sense that they constitute fitting material for re-shaping the representation of the past in modern Vietnam and narratives about national and revolutionary martyrs [45]. As in other Asian countries where the dead were 'employed' in the service of national unity (see $[25,29])$, in Vietnam the belief in life after death and especially in the "exceptional dead" became a potent symbol of national integration linking society with its heroic history ([33]; see also [24, 28, 31]). Van der Veer and Lehmann ([55], p. 11) argue that "death and afterlife form the stuff of which both religion and nationalism are made." Consequently, in Vietnam ancestor worship has recurred as a "hero-centered political culture" in which the center of gravity is the exemplary service of the ancestors rather than their peaceful afterlife ([31], p. 104).

Arvind-Pal Mandair [34] argues that the ability to establish a connection between past and present concentrates around a re-evaluation of the role of religion and language which are "crucial components in the formation of nationalism." Trans- 
forming and shaping local notions of 'religion' congruent with a quest for national identity stimulates the state not only to change its attitude toward popular culture but also to extract these values and moral guidelines from a rich repertoire of religious traditions, which give legitimacy to the State. Mandair [34] calls such a process a return of "the political to its religious sources" which is a "self-legitimating or selfreferencing phenomenon." Taking all this into account I conclude that religious traditions previously associated with 'backwardness,' 'feudalism' and 'irrationality,' just to mention a few illustrative pejoratives, have become powerful forms of nationbuilding and crucial instruments for preserving a tradition-oriented national identity against the alleged 'negative effects of foreign culture' insidiously slithering into Vietnam in the form of mass culture. Simultaneously, in this process, both religion and nation-building have turned out to be a creative space filled with spirited dialogues, negotiations and contestations, a space in which different individuals and groups exercised their agency beyond resistance and accommodation and sought to accomplish in - Ortner's [39] terms - their own "culturally constituted projects."

Acknowledgements Research in the National Library of Vietnam (Hanoi) for this article was supported by the grant of the Polish Ministry of Education and Sport in 2005. Fieldwork on Lý Sơn Island was made possible thanks to the doctoral grant of the Max Planck Institute for Social Anthropology in Halle, Germany. I also would like to thank the Center of Asia-Pacific Area Studies, Academia Sinica which provided support, both in terms of office space and library resources. Additionally, I am indebted to Kirsten Endres for drawing my attention to the Công Báo documents during our discussion in Hanoi 2004. I am also grateful to Claire Sutherland for her editorial work on this issue, and to Oscar Salemink and two anonymous reviewers for East Asia for their excellent comments on a previous version of this article.

\section{References}

1. Amer, R. (2002). The Sino-Vietnamese approach to managing boundary disputes. Durham: International Boundaries Research Unit.

2. Anagnost, A. S. (1994). The politics of ritual displacement. In Ch. F. Keyes, L. Kendall \& H. Hardacre (Eds.), Asian visions of authority: Religion and the modern states of East and Southeast Asia (pp. 221-254). Honolulu University of Hawaii Press.

3. Boudarel, G. (1991). L'insertion du pouvoir central dans les cultes villageois au Vietnam: Esquisse des problèmes à partir des écrits de Ngô Tat Tô. In A. Forest, Y. Ishizawa \& L. Vandermeersch (Eds.), Cultes populaires et societétés asiatiques: Appareils cultuels et appareils de pouvoir (pp. 87-144). Paris: Centre National de la Recherche Scientifique, l'Université Paris, l'Institute of Asian Cultures, l'Universté Sophia (Tôkyô).

4. Comaroff, J. (1985). Body of power spirits of resistance: The culture and history of a South African people. Chicago and London: The University of Chicago Press.

5. Công Báo (1955a). Sắc Lệnh số 234-SL ngày 14-6-1955 ban hành chính sách tôn giáo [Decree no. 234-SL of 14-6-1955 on the promulgation religious policy], số [no.] 11, 154-155.

6. Công Báo (1955b). Nghị định số 559 -TTg ngày 14-7-1955 định mức thuế nông nghiệp cho những phần ruộng đất mà nhà thờ, nhà chùa, thánh thất được sử dụng từ sau cải cách ruộng đất [Decree no. 559 - TTg of 14-7-1955 on agricultural tax normalization of land used by churches, Buddhist pagodas, and oratories since the land reform], số [no.] 12, 172.

7. Công Báo (1956). Thông tư số 954 - ngày về việc bảo vệ những di tích lịch sư [Circular no.954 - TTg on the protection of places of historical interest], số [no.] 20, 189.

8. Công Báo (1960). Thông Tư số 165/VH/VP ngày 2-2-1960 về việc bảo quản, sử dụng, tu sửa các công trình kiến trúc chưa xếp hạng (đình, chùa, lăng, miếu, cầu, quán, nhà thờ, mồ mả, v.v... ) và các động sản phụ thuộc (bia, đồ thờ, đồ trang trí, cây cổ thụ, v.v...) [Circular Letter no. 165/VH/VP of 2- 
2-1960 on the preservation, use, and repair of architectural constructions that have not been yet classified (communal houses, pagodas, imperial tombs, temples, roadside shrines, palaces, churches, graves, etc.) and personal assets (tombstones, cult objects, decoration objects, century-old trees, etc.)], số [no.]19, 338.

9. Công Báo (1962). Quyết định số 313-VH/VP ngày 28-4-1962 về việc xếp hạng những di tích, danh thắng toàn miền Bắc [Decision no. 313-VH/VP of 28-4-1962 on the classification of monuments and places of natural beauty in North Vietnam], số [no.] 21, 340.

10. Công Báo (1966). Chỉ thị số 188-TTg/VG ngày 24-10-1966 về việc bảo vệ và phát huy tác dụng của di tích lịch sử trong thời gian chống Mỹ cứu nước [Directive no.188-TTg/VG of 24-10-1966 on the protection and development of places of historical interest at the time of resistance against the American aggressors for national salvation], số [no.] 13, 270.

11. Công Báo (1973). Chỉ thị số 88-TTg ngày 26-4-1973 về việc chấp hành chính sách đối với việc bảo vệ các chùa thờ Phật và đối với tăng ni [Directive no. 88 -TTg of 26 - 4-1973 on the implementation of the policy on protection of Buddhist pagodas and clergy], số [no.] 15, 252-254.

12. Công Báo (1974). Quyết định số 15-VH/QĐ ngày 13-3-1974 về việc xếp hạng di tích lịch sử và văn hóa đợt III [Decision no. 15-VH/QĐ of 13-3-1974 on the classification of historical and cultural monuments, 3rd stage], số [no.] 4, 51.

13. Công Báo (1975). Quyết định số 09-VH/QĐ ngày 21-2-1975 việc xếp hạng di tích lịch sử và văn hóa đợt IV [Decision no. 09-VH/QĐ of 21-2-1975 on the classification of historical and cultural monuments, 4th stage], số [no.] 6, 91.

14. Công Báo (1980). Quyết định số 92-VH/QĐ ngày 10-7-1980 xếp hạng 17 di tích lịch sử và văn hóa [Decision no. 92-VH/QĐ of 10-7-1980 on the classification of 17 historical and cultural monuments], số [no.] 12, 230-232.

15. Công Báo (1982). Quyết định số 147-VH/QĐ ngày 24 -12-1982 xếp hạng 8 di tích lịch sử và văn hóa [Decision no. 147-VH/QĐ of 24-12-1982 on the classification of 8 historical and cultural monuments], số [no.] 25, 532.

16. Công Báo (1984). Pháp Lệnh ngày 31-3-1984 bảo vệ và sử dụng di tích lịch sử, văn hóa và danh lam, thăng cảnh [State Law of 31-3 -1984 on the protection and use of places of historical and cultural interest and of beautiful landscape], số [no.] 8, 154.

17. Công Báo (2001). Luật Di sản văn hóa, số 28/2001/QH10 ngày 29/6/2001[State Law on Cultural Heritage, no. 28/2001/QH10 ngày 29/6/2001], số [no.] 34, 2231-2243.

18. Công Báo (2002). Nghị Định của Chính phủ số 92/20002/NĐ-CP ngày 11/11/2002 quy định chi tiết thi hành một số điều của Luật Di sản văn hóa [Decree of the Government no. 92/2002 NĐ-CP of 11/ 11/2002 ] on elaboration of the implementation of some clauses of State Law on Cultural Heritage], số [no.] 61, 4045-4066.

19. DiGregorio M. \& Salemink O. (2007). Living with the dead: The politics of ritual and remembrance in contemporary Vietnam. Journal of Southeast Asian Studies, 38 (3), 443-440.

20. Do, Thien. (2003). Vietnamese supernaturalism: Views from the southern region. London and New York: RoutledgeCurzon and Francis Group.

21. Endres, K. W. (2000). Ritual, Fest und Politik in Nordvietnam: zwischen Ideologie und Tradition. Münster: LIT Verlag.

22. Endres, K. W. (2001). Local dynamics of renegotiating ritual space in Northern Vietnam: The case of the dinh. Sojourn, 16 (1),70-71.

23. Endres, K. W. (2002). Beautiful customs, worthy traditions: Changing state discourse on the role of Vietnamese culture. Internationales Asienforum, 33 (3-4), 303-322.

24. Endres, K. W. (2008). Engaging the spirits of the dead: Soul-calling rituals and the performative construction of efficacy. Journal of the Royal Anthropological Institute (14), 755-773.

25. Evans, G. (1998). The politics of ritual and remembrance: Laos since 1975. Honolulu: University of Hawai'i Press.

26. Gellner, E. (1983). Nations and nationalism. Oxford: Blackwell.

27. Hobsbawm, E. J. \& Ranger, T. O. (1983). The invention of tradition. Cambridge [Cambridgeshire]; New York: Cambridge University Press.

28. Ho Tai, Hue Tam. (2001). The country of memory: Remaking the past in late socialist Vietnam. Berkeley: University of California Press.

29. Keyes, Ch. F. (2002). National heroine or local spirit? The struggle over memory in the case of Thao Suranari of Nakhon Ratchasima. In Tanabe Shigeharu and Charles F. Keyes (Eds.), Cultural crisis and social memory: Modernity and identity in Thailand and Laos (pp. 113-135). London: RoutledgeCurzon. 
30. Keyes, Ch. F., Laurel Kendall \& H. Hardacre (Eds.). (1994). Introduction: Contested visions of community in East and Southeast Asia. In Ch. F. Keyes, L. Kendall \& H. Hardacre (Eds.), Asian Visions of Authority: Religion and the Modern States of East and Southeast Asia. Honolulu University of Hawaii Press.

31. Kwon, H. (2006). After the massacre: Commemoration and consolation in Ha My and My Lai. Berkeley, Los Angeles and London: University of California Press.

32. Lê Quý Đôn. (1972 [1776]). Phủ Biên Tạp Lục [A Compilation of the Miscellaneous Records When the Southern Border was Pacified], vol.1, Saigon: Phủ Quốc Vụ Khạnh Đặc Trách Văn Hóa.

33. Malarney, S. K. (2007). Festivals and the dynamics of the exceptional dead in Northern Vietnam. Journal of Southeast Asian Studies 38 (8), 515-540.

34. Mandair, Arvind-Pal S. (2009). Religion and the specter of the West: Sikhism, India, postcoloniality, and the politics of translation. New York: Columbia University Press.

35. Mbembe, A. (1992). The banality of power and the aesthetics of vulgarity in the postcolony. Public Culture, 4 (2), 1-30.

36. Migdal, J. S. (1994). The State in society: An approach to struggles for domination. In J. S. Migdal, A. Kohli \& V. Shue (Eds.), State power and social forces: Domination and transformation in the third world (pp. 5-34). Cambridge and New York: Cambridge University Press.

37. Nguyễn Nhã. (1975). Đặc Khảo về Hoàng sa và Trường Sa [Solid research on the Paracel and Spratly]. Sủ Địa 29 (1-3), 258-273.

38. Ninh, Kim N.B. (2002). A World of political transformed: The politics of culture in revolutionary Vietnam, 1945-1965. Ann Arbor: The University of Michigan Press.

39. Ortner, S. B. (1995). Resistance and the problem of ethnographic refusal. Comparative Studies in Society and History, 37 (1), 173-193.

40. Ortner, S. B. (2006). Anthropology and social theory: Culture, power and the acting subject. Durham and London: Duke University Press.

41. Pelley, P. M. (2002). Postcolonial Vietnam: New histories of the national past. Durkham: Duke University Press.

42. Pham, Quynh Phuong. (2009). Hero and deity: Tran Hung Dao and the resurgence of popular religion in Vietnam. Chiang Mai: Mekong Press.

43. Roszko, E. (2010). Commemoration and the state: Memory and legitimacy in Vietnam. Sojourn: Journal of Social Issues in Southeast Asia, Vol. 25. no. 1, pp.1-28.

44. Salemink, O. (2007). The Emperor's new clothes: Re-fashioning ritual in the Huế festival. Journal of Southeast Asian Studies, 38 (3),559-582.

45. Salemink, O. (2008). Spirits of consumption and the capitalist ethic in Vietnam. In P. Kitiarsa (Eds.) Religious commodifications in Asia: Marketing gods (pp. 147-168). London and New York: Routledge.

46. Salemink, O. (forthcoming). Appropriating culture: The politics of intangible cultural heritage in Vietnam. In Hue-Tam Ho Tai \& M. Sidel (Eds.) Property and power: State, society and market in Vietnam. New York and London: Routledge.

47. Sutherland, C. (2005). Nation-building through discourse theory. Nations and Nationalism, 11 (2), $185-202$.

48. Sutherland, C. (2006). Calculated conviction: Contemporary nationalist ideology and strategy. Studies in Ethnicity and Nationalism, 6 (1), 69-89.

49. Taylor, P. (2001). Fragments of the present: Searching for modernity in Vietnam's South. Honolulu: University of Hawaii Press.

50. Taylor, P. (2007). Modernity and re-enchantment: Religion in post-revolutionary Vietnam (pp. 194220). Singapore: ISEAS.

51. Trần, Quốc Vượng. (1992). Popular culture and high culture in Vietnamese history. An Interdisciplinary Journal of Southeast Asian Studies, 7 (2), 5-38.

52. Trần, Quốc Vượng. (1995). The legend of Ông Dóng from the text to the field. In K. W. Taylor \& J. Whitmore (Eds.) Essays into Vietnamese Pasts (pp.13-41). New York: Cornell University Press.

53. Truong, Huyen Chi. (2001). Changing processes of social reproduction in the Northern Vietnam countryside: An Ethnographic study of Đồng Vàng village (Red River Delta). Ph.D. Toronto: University of Toronto.

54. Truong, Huyen Chi. (2004). Winter Crop and spring festival: The contestations of local government in a Red River Delta commune. In Benedict J. Kerkvliet Tria \& D. G. Marr, Beyond Hanoi: Local Government in Vietnam (pp.110-136). Singapore: Institute of Southeast Asian Studies.

55. Van der Veer, P. \& Lehmann, H. (1999). Nation and religion: Perspectives on Europe and Asia. Princeton, N.J.: Princeton University Press. 
56. Weber, M. (2004). The vocation lectures. D. Owen \& T. B. Strong (Eds.) Indianapolis: Hackett Publishing Company.

57. Whitmore, J. K. (1980). Bureaucratic control of the spirits in Vietnam. Association of Asian Studies, Washington, D.C.

58. Whitmore, J. K. (1984). Social organization and Confucian thought in Vietnam. Journal of Southeast Asian Studies, 15 (2), 296-306.

59. Wolters, O. W. (1988). Two essays on Đại-Việt in the fourteenth century. New Heaven CT: Council of Southeast Asian Studies, Yale Centre for International and Area Studies. 